\title{
COLD TOLERANCE OF BANANA FRUITS OF DIFFERENT CULTIVARS ${ }^{1}$
}

\author{
JOÃO ALISON ALVES OLIVEIRA ${ }^{2 *}$, LUIZ CARLOS CHAMHUM SALOMÃO ${ }^{2}$, DALMO LOPES DE SIQUEIRA ${ }^{2}$, \\ PAULO ROBERTO CECON ${ }^{2}$
}

\begin{abstract}
The objective of this work was to evaluate the tolerance of fruits of different banana cultivars to low temperature storages. Fruits of the cultivars Nanicão (AAA), Prata (AAB), Vitória (AAAB), Maçã (AAB) and Caipira (AAA) were used. Clusters of three fruits were kept in cold storage for 7, 14 and 21 days, with average temperature of $10.53 \pm 0.37^{\circ} \mathrm{C}$ and relative humidity of $85 \%$. Subsequently, the clusters were transferred to temperatures of $22 \pm 0.39^{\circ} \mathrm{C}$ and evaluated for 16 days. The fruits of all cultivars remained green after 21 days of storage at $10.53 \pm 0.37^{\circ} \mathrm{C}$. Fruits of the cultivar Nanicão did not completely ripened after transferred to the $22^{\circ} \mathrm{C}$ storage, when stored for 7 days at low temperature. These fruits were firmer, with green peel and low soluble solids and titratable acidity. The fruits of all cultivars complete the ripening when transferred to room temperature after 21 days of cold storage. Chilling injuries increased with cold storage time in all cultivars. The cultivars Nanicão, Caipira and Maçã had more symptoms of chilling injury, while Prata and Vitória were more tolerant to the cold storage $\left(10.53^{\circ} \mathrm{C}\right)$ for up to 21 days, showing normal ripening after transferred to the $22 \pm 0.39^{\circ} \mathrm{C}$ storage.
\end{abstract}

Keywords: Musa spp. Chilling injury. Storage. Shelf life.

\section{TOLERÂNCIA AO FRIO DE FRUTOS DE DIFERENTES CULTIVARES DE BANANEIRAS}

RESUMO - O objetivo deste trabalho foi avaliar a tolerância dos frutos de diferentes cultivares de bananeira a baixa temperatura de armazenamento. Foram utilizados frutos das bananas Nanicão (AAA), Prata (AAB), Vitória (AAAB), Maçã (AAB) e Caipira (AAA). Utilizaram-se buquês com três frutos, mantidos em câmara fria por 7, 14 e 21 dias, com temperatura média de $10,53 \pm 0,37^{\circ} \mathrm{C}$ e umidade relativa do ar de $85 \%$. Posteriormente, os buquês foram transferidos para a temperatura de $22 \pm 0,39^{\circ} \mathrm{C}$ e avaliados por 16 dias. Os frutos dos cultivares estudados peraneceram verdes após 21 dias de armazenamento a $10,53 \pm 0,37^{\circ} \mathrm{C}$. Frutos do Nanicão não completaram o amadurecimento após serem transferidos para a temperatura de $22^{\circ} \mathrm{C}$, quando armazenados por 7 dias à baixa temperatura, apresentando frutos mais firmes, com casca verde, baixos teores de sólidos solúveis e acidez titulável. Após 21 dias de armazenamento refrigerado, os frutos de todos os cultivares completaram o amadurecimento, depois de transferidos para temperatura ambiente. Os danos por frio aumentaram com o avanço do tempo de armazenamento refrigerado, para todos os cultivares. Nanicão, Caipira e Maçã apresentaram sintomas mais evidentes de dano por frio. As bananas Prata e Vitória mostraram-se mais tolerantes ao armazenamento refrigerado na temperatura de $10,53^{\circ} \mathrm{C}$ por até 21 dias, exibindo amadurecimento normal após a transferência para a temperatura de $22^{\circ} \mathrm{C}$.

Palavras-chave: Musa spp. Injúria por frio. Armazenamento. Vida de prateleira.

\footnotetext{
*Corresponding author

${ }^{1}$ Received for publication in $04 / 28 / 2015$; accepted in 05/07/2016.

Paper extracted from the masters thesis of the first author.

${ }^{2}$ Department of Fitotecnia, Universidade Federal de Viçosa, Viçosa, MG, Brazil. joao.alison@yahoo.com.br, 1salomao@ufv.br, siqueira@ufv.br, cecon@ufv.br.
} 


\section{INTRODUCTION}

Banana (Musa spp.) is one of the most cultivated fruit in tropical and subtropical countries. Brazil is the sixth largest world producer, with 6.9 million tons of bananas and plantains and 481,000 hectares harvested in 2012 (FAO, 2014).

However, Brazilian exports of bananas is small. The low postharvest management technology used is one of the restrictive factors for export. In general, the national product does not meet the European and North American market requirements, especially regarding organoleptic and visual aspects (LICHTEMBERG; LICHTEMBERG, 2011).

Banana ripening is an irreversible process, characterized by a climacteric respiratory pattern, which is stimulated by an autocatalytic production of ethylene and physiological and metabolic changes that are sensitive to temperature and ethylene itself (XIAO et al., 2013). Several studies have been conducted on control postharvest banana quality, discussing storage conditions and treatments to prolong its shelf life (FERNANDES et al., 2010; WANG et al., 2014; ZHANG et al., 2010). The maintenance of cold storage from harvesting to marketing is undoubtedly the main technique available to delay senescence of plants (MARTINS et al., 2007).

Although low temperature storages $\left(<13^{\circ} \mathrm{C}\right)$ slow fruit ripening and prolong its shelf-life, beneficial effects are limited by disorders associated with chilling injury, including peel browning and ripening problems (NGUYEN et al. 2003; PROMYOU et al., 2008).

Chilling injury symptoms vary depending on the banana cultivar and appear to be related to a genomic group (LICHTEMBERG et al., 2001). Fernandes et al. (2010) reported that a temperature of $13^{\circ} \mathrm{C}$ is effective in delaying ripening of bananas (cultivar Nanicão) stored for 17 days. Bananas (cultivar Prata-Anã) stored for 35 days at temperatures of 10 to $12^{\circ} \mathrm{C}$ showed no symptoms of chilling injury (MARTINS et al., 2007).

The scientific literature provides little information about the banana cultivars planted in Brazil regarding cold storage, limiting the application of conservation techniques and transportation over long distances.

The objective of this work was to evaluate the tolerance of bananas (cultivars Prata, Nanicão, Vitória, Maçã, and Caipira) to low temperature storage.

\section{MATERIAL AND METHODS}

Banana bunches (Musa spp.) of cultivars Prata (AAB), Nanicão (AAA), Vitória (AAAB), Maçã (AAB) and Caipira (AAA) were collected in an experimental orchard (five-year-old plants spaced $3.5 \times 2.5 \mathrm{~m}$ ) of the Viçosa Federal University (UFV), State of Minas Gerais $\left(20^{\circ} 45^{\prime} \mathrm{S}, 42^{\circ} 51^{\prime} \mathrm{W}\right.$ and altitude of $650 \mathrm{~m}$ ) in March 2014. The regional climate is Cwa, according to the Köppen classification, with annual averages of temperature of $26.1^{\circ} \mathrm{C}$, precipitation of $1,340 \mathrm{~mm}$ and relative humidity of $80 \%$.

The bunches were harvested in the preclimacteric stage, the color 1 stage (totally green peel) (DADZIE; ORCHARD, 1997). Clusters of three fruits, uniform in weight and diameter, were chosen from the second, third and fourth clusters. In the Fruit Analysis Laboratory (UFV). The clusters were washed with water and mild detergent $(0.2 \%)$ for $5 \mathrm{~min}$ for latex coagulation and surface cleaning and immersed in a fungicide solution (Prochloraz at $0.49 \mathrm{~g} \mathrm{~L}^{-1}$ ) for $5 \mathrm{~min}$ and air dried.

Subsequently, the clusters were stored in a cold chamber for 7, 14 and 21 days. The temperature of the chamber was $10.53 \pm 0.37^{\circ} \mathrm{C}$ and average relative humidity of air of $85 \%$. After the storage periods, the bunches were transferred to another chamber at temperature of $22 \pm 0.39^{\circ} \mathrm{C}$. Samples were taken for analysis on the storage day (day 0) and after storage periods (day 7,14 and 21 ) at $0,2,4,6$, $8,10,12,14$ and 16 days after the transference to the chamber at $22 \pm 0.39^{\circ} \mathrm{C}$. The fruit samples were subjected to analysis of peel color index and hue angle, weight loss, firmness, soluble solids and titratable acidity of pulp, incidence of chilling injury in the peel, total phenolic compounds and activity of polyphenol oxidase in the peels.

The peel color was evaluated with the visual color scale described by Dadzie and Orchard (1997), which ranges from stage 1 (totally green peel) to 7 (totally yellow peel with brown spots). A colorimeter Konica Minolta (CR-10, Konica Minolta Sensing, Japan) was also used, with readings expressed as module $\mathrm{L}^{*}, \mathrm{a}^{*}, \mathrm{~b}^{*}$, according to the CIE Color System (1976), and results expressed as hue angle, $\mathrm{h}=\tan ^{-1}\left(\mathrm{~b}^{*} / \mathrm{a}^{*}\right)$.

The weight loss of the fruits was evaluated gravimetrically and expressed in percentage considering the difference between the initial and final (evaluated at each sampling) weight. The pulp firmness was evaluated using a penetrometer (Shimpo-DFS100, Digital Force Gauge) in the middle region of each fruit, after the removal of part of the peel without pulp injury. The results were expressed in Newton (N).

Soluble solids (SS) in the pulp were evaluated in a portable refractometer (Atago, Model N1, Japan) that reads a range of 0 to $32^{\circ} \mathrm{Brix}$ and titratable acidity (TA), according to the methodology described by Adolfo Lutz Institute (2008). The results were expressed in grams of malic acid per $100 \mathrm{~g}$ of pulp.

The incidence of chilling injury was evaluated with a 1-5 scale, based on the darkening intensity of 
the peel surface (NGUYEN et al., 2003), where $1=$ no chilling injury, $2=$ light injury, $3=$ moderate injury, $4=$ severe injury, and $5=$ very severe injury.

The total phenolic content was evaluated by the Folin-Ciocalteu spectrophotometric method (Sigma-Aldrich, USA), as described by Singleton et al. (1999), using gallic acid as standard and results expressed as gallic acid equivalents (GAE) in milligrams per $100 \mathrm{~g}$ of plant tissue, based on wet weight.

The activity of polyphenol oxidase (PPO) was evaluated according to the methodology described by Flurkey and Jen (1978) and Maia et al. (2014), with modifications. The enzyme extract was obtained by taking $1 \mathrm{~g}$ of peel with $5 \mathrm{~mL}$ of phosphate buffer 0.2 $\mathrm{M}$ (pH 6.0), cooling in an ice bath, triturate in polytron at $20,500 \mathrm{rpm}$ for $40 \mathrm{~s}$ and centrifuge the suspension at $10,000 \mathrm{~g}$ for 21 minutes at $4^{\circ} \mathrm{C}$. The activity was evaluated by seven absorbance readings 30 seconds apart, using a spectrophotometer at 425 $\mathrm{nm}$. Results were expressed in enzyme units per gram of sample, calculated from the amount of extract that an increase in absorbance of 0.001 units per minute.

A split-plot scheme was used, with parcels consisting of five cultivars and the subplots consisting of evaluation days, in a completely randomized design with four replications with a three-fruit cluster per sample unit. Each storage period was an experiment apart. Data were subjected to analysis of variance, regression and Dunnett's test at 5\% probability, comparing the control (fruits at the day in which the storage began) data with the days in which the storages ended, using the SAEG9.1 program (SAEG, 2007). Descriptive analysis was used for the data of polyphenol oxidase activity of the peels.

\section{RESULTS AND DISCUSSION}

There was no difference in peel color index between the control and after the storage periods
(SP). All fruits remained green with peel color index of 1 after 7, 14 and 21 days of storage (Table 1). Similar results were found by Martins et al. (2007) in banana Prata-Anã stored at 10 to $12^{\circ} \mathrm{C}$, with completely green fruit after 35 days. After the transference of the fruits to the chamber at $22 \pm 0.39^{\circ}$ $\mathrm{C}$, a sigmoidal pattern was found in the increase of the peel color index as a function of the periods evaluated for the five cultivars and three periods of storage (Figure 1A), except for Nanicão and Vitória in SP of 7 days.

The cultivars Caipira, Prata and Maçã needed 11.4, 12.8 and 13.6 days, respectively, for complete the ripening (index color 6) after the SP of 7 days at $10.53 \pm 0.37^{\circ} \mathrm{C}$ (Figure $1 \mathrm{~A} 1$ ). The cultivars Caipira, Maçã, Prata and Vitória required 4.7, 7.2, 9.2 and 11.2 days, respectively for complete the ripening after the SP of 14 days (Figure 1A2). The cultivars Prata, Caipira, Vitória and Maçã required 3.8, 4.0, 7.6 and 7.7 respectively, for complete the ripening after the SP of 21 days, while the Nanicão complete ripened after 13.6 days (Figure $1 \mathrm{~A} 3$ ).

The loss of green color in bananas is due to the structural decomposition of chlorophyll by enzyme systems alone or together with chlorophyllase on chloroplasts, showing the yellow color (CHITARRA; CHITARRA, 2005). The peel color of banana is generally well correlated with the maturation of the fruit, an important parameter for shelf life and to the consumer decision-making on whether to buy or not the fruit (MATSUURA et al., 2004).

The cultivar Caipira after SP of 7 days and Nanicão, Maçã and Caipira after SP of 21 days showed hue angle values lower than the control (Table 1). However, this difference did not result in changes in the visual color of fruits, which remained green at the storage period. The peel hue angle presented a sigmoidal pattern as a function of the periods evaluated at temperature of $22 \pm 0.39^{\circ} \mathrm{C}$ for the five cultivars and three periods of storage (Figure 1B).

Table 1. Peel color index, peel hue angle, fresh weight loss, pulp firmness, soluble solids and titratable acidity means of fruits of five banana cultivars before and after different storage periods at temperature of $10,53 \pm 0,37^{\circ} \mathrm{C}$.

\begin{tabular}{cccccc}
\hline \multirow{2}{*}{ Treatments } & Nanicão & Vitória & Prata & Maçã & Caipira \\
\cline { 2 - 6 } & \multicolumn{5}{c}{ Peel color index } \\
\hline Control $^{1}$ & 1.0 & 1.0 & 1.0 & 1.0 & 1.0 \\
\hline 7 D & 1.0 & 1.0 & 1.0 & 1.0 & 1.0 \\
\hline 14 D & 1.0 & 1.0 & 1.0 & 1.0 & 1.0 \\
\hline 21 D & 1.0 & 1.0 & 1.0 & 1.0 & - \\
\hline CV $^{2}(\%)$ & - & - & - & - & 117.8 \\
\hline Control $^{1}$ & 119.6 & 117.4 & 118.3 & $115.3^{*}$ \\
7 D & 117.6 & 117.5 & 117.7 & 117.3 & 116.5 \\
14 D & 117.9 & 117.8 & 117.4 & 116.9 & $116.1^{*}$ \\
\hline 21 D & $116.4^{*}$ & 117.7 & 116.8 & $114.6^{*}$ & 0.89 \\
\hline CV $^{2}(\%)$ & 1.04 & 0.80 & 0.67 & 1.03 & $\left.{ }^{\circ}\right)$ \\
\hline
\end{tabular}

Means followed by * statistically differed from the control by the Dunnett's test, at $5 \%$ of probability; ${ }^{1}$ Mean from the fruits at the storage beginning; ${ }^{2}$ Coeficient of variation. $\mathrm{D}=$ days.

Rev. Caatinga, Mossoró, v. 29, n. 3, p. 629 - 641, jul. - set., 2016 
Table 1. Continuation.

\begin{tabular}{|c|c|c|c|c|c|}
\hline \multirow{2}{*}{ Treatments } & Nanicão & Vitória & Prata & Maçã & Caipira \\
\hline & \multicolumn{5}{|c|}{ Peel color index } \\
\hline \multicolumn{6}{|c|}{ Fresh weight loss (\%) } \\
\hline Control $^{1}$ & 0.00 & 0.00 & 0.00 & 0.00 & 0.00 \\
\hline $7 \mathrm{D}$ & $0.41 *$ & $0.62 *$ & $0.94 *$ & $0.85^{*}$ & $0.56^{*}$ \\
\hline $14 \mathrm{D}$ & $1.76^{*}$ & $2.04 *$ & $2.14^{*}$ & $2.04 *$ & $1.71 *$ \\
\hline $21 \mathrm{D}$ & $2.58 *$ & $2.52 *$ & $2.74 *$ & $2.74 *$ & $2.51 *$ \\
\hline $\mathrm{CV}^{2}(\%)$ & 17.88 & 16.49 & 12.47 & 11.78 & 19.88 \\
\hline \multicolumn{6}{|c|}{ Firmness $(\mathrm{N})$} \\
\hline Control $^{1}$ & 42.9 & 29.7 & 39.7 & 37.4 & 39.9 \\
\hline $7 \mathrm{D}$ & 41.8 & 32.9 & 32.1 & 33.6 & 35.3 \\
\hline $14 \mathrm{D}$ & 38.7 & 30.8 & 30.9 & $28.6^{*}$ & $32.3 *$ \\
\hline $21 \mathrm{D}$ & 43.2 & 27.0 & 32.6 & $28.2 *$ & $17.5^{*}$ \\
\hline $\mathrm{CV}^{2}(\%)$ & 12.77 & 11.93 & 17.76 & 9.14 & 12.97 \\
\hline \multicolumn{6}{|c|}{ Soluble solids ( $\left.{ }^{\circ} \mathrm{Brix}\right)$} \\
\hline Control $^{1}$ & 9.63 & 11.67 & 10.50 & 10.99 & 8.58 \\
\hline $7 \mathrm{D}$ & 11.27 & 13.13 & 10.41 & 11.88 & 9.73 \\
\hline $14 \mathrm{D}$ & 10.88 & 13.25 & $13.41 *$ & $12.99 *$ & 8.87 \\
\hline $21 \mathrm{D}$ & $12.31 *$ & 13.98 & $15.34 *$ & $13.73 *$ & 9.73 \\
\hline $\mathrm{CV}^{2}(\%)$ & 10.03 & 8.14 & 9.52 & 8.01 & 10.04 \\
\hline \multicolumn{6}{|c|}{ Titratable acidity (g of malic acid per $100 \mathrm{~g}^{-1}$ of pulp) } \\
\hline Control $^{1}$ & 0.294 & 0.292 & 0.209 & 0.203 & 0.255 \\
\hline $7 \mathrm{D}$ & 0.322 & 0.279 & 0.223 & $0.264 *$ & 0.279 \\
\hline $14 \mathrm{D}$ & 0.324 & 0.306 & $0.312 *$ & $0.274 *$ & 0.284 \\
\hline $21 \mathrm{D}$ & 0.337 & 0.330 & $0.303^{*}$ & $0.292 *$ & $0.346^{*}$ \\
\hline $\mathrm{CV}^{2}(\%)$ & 13.09 & 12.92 & 12.15 & 9.39 & 8.40 \\
\hline
\end{tabular}

Means followed by * statistically differed from the control by the Dunnett's test, at $5 \%$ of probability; ${ }^{1}$ Mean from the fruits at the storage beginning; ${ }^{2}$ Coeficient of variation. $\mathrm{D}=$ days.

The hue values decreased with increasing storage time (Figure 1B). After 21 days of storage, the cultivar Nanicão remained with virtually green peel until the $10^{\text {th }}$ day, with average hue value of $23.70 \%$, which was the highest among the cultivars, while the other cultivars presented fruits completely yellow on the $8^{\text {th }}$ day with hue values of $81.16^{\circ}$ to $88.06^{\circ}$ (Figure 1 B3). This result confirms that Nanicão has longer shelf life and high potential for commercialization over long distances.

The fresh weight loss was different from the control in all storage periods and cultivars (Table 1). Figure 2A shows that the fresh weight loss increased linearly as a function of the periods evaluated after the transference to a temperature of $22 \pm 0.39^{\circ} \mathrm{C}$ for all cultivars and three SP.

The fresh weight loss increased with the fruits ripening. The cultivar Maçã had the greatest fresh weight losses, with 6.57 (D 7), 7.83 (D 14) and $10.38 \%$ (D 21), on the $16^{\text {th }}$ day at temperature of $22 \pm 0.39^{\circ} \mathrm{C}$, while Nanicão had the lowest losses, with 3.98 (D 7), 4.71 (D 14) and 6.48\% (D 21).

According to Finger et al. (1995), fresh weight losses affect the pre-climacteric phase in banana Robusta (Musa acuminata Colla), and a fresh weight loss of $5 \%$ reduces in seven days and a loss of $10 \%$ in ten days the pre-climacteric period. In the present study, fruits from cultivars with higher fresh weight losses ripened faster according to the color index, indicating a reduction in the pre-climacteric period.

Moisture losses in fruits of 3 to $6 \%$ are sufficient to cause a marked decrease in quality, but some products are marketed even with $10 \%$ moisture loss (CHITARRA; CHITARRA, 2005). Although the fresh weight loss found have exceeded these values, there was no wilt symptoms in the fruits.

The pulp firmness of the cultivars Maçã and Caipira was different from the control when stored for 14 and 21 days at $10.53 \pm 0.37^{\circ} \mathrm{C}$ (Table 1), with reductions of 24.66 (Maçã) and 56.32\% (Caipira) in pulp firmness values after 21 days of storage. This result indicates that transport to long distances may not be feasible, since the fruits would reach their destination with softened pulp, and thus, with marketing restricted to local markets. The other cultivars the fruits remained firm after 21 days of storage. Salvador et al. (2007) found pulp firmness values unchanged after bananas from the AAA and $\mathrm{AAB}$ groups were stored at $10^{\circ} \mathrm{C}$ for 16 days.

The greater the cold storage period, the lower the ripening period at room temperature. The cultivars Caipira, Prata and Maçã softened more quickly after the cold storage periods (Figure 2B). 
Reductions in the fruit firmness usually occur due to enzymes that act in the cell wall (CHITARRA; CHITARRA, 2005; MATSUURA et al., 2004).

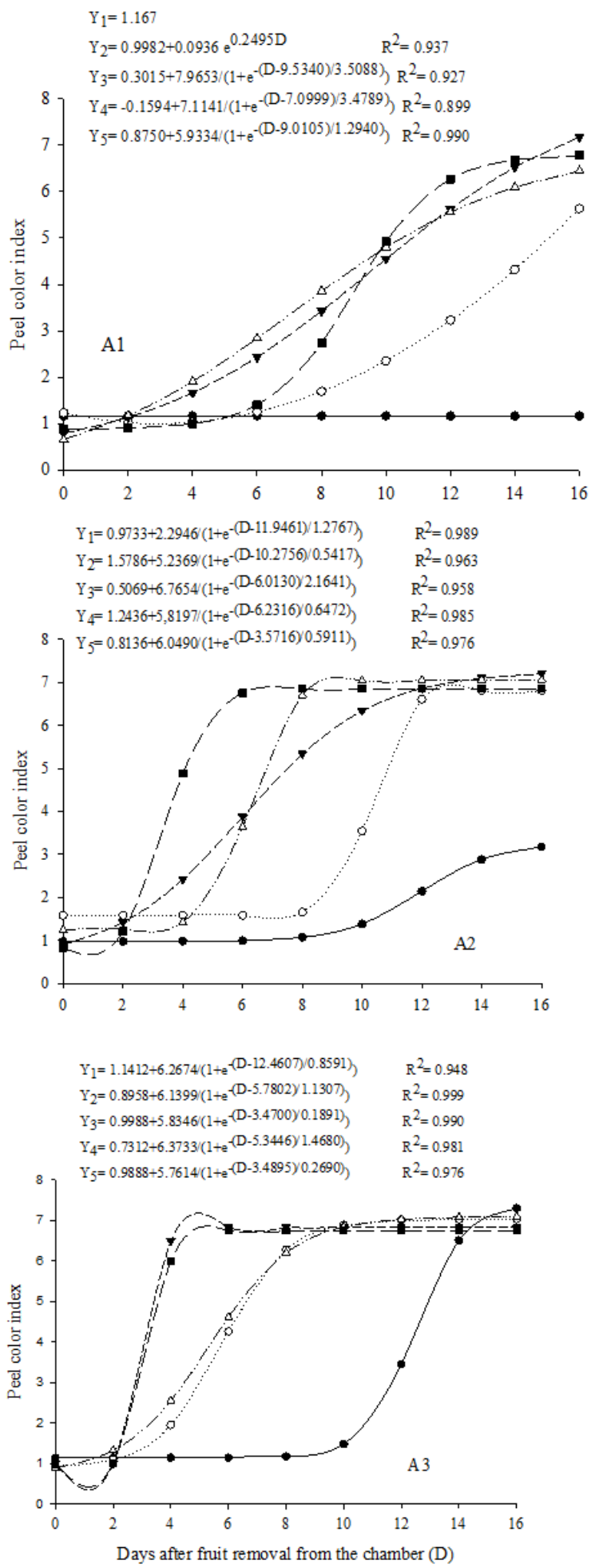

Overall, in this study, the cold storage was effective in preventing the softening of fruits of the cultivars.



Figure 1. Peel color index (A) and hue angle (B) of bananas as a function of the periods evaluated after 7 (1), 14 (2) and 21 (3) days of storage at temperature of $10.53 \pm 0.37^{\circ} \mathrm{C}$. 


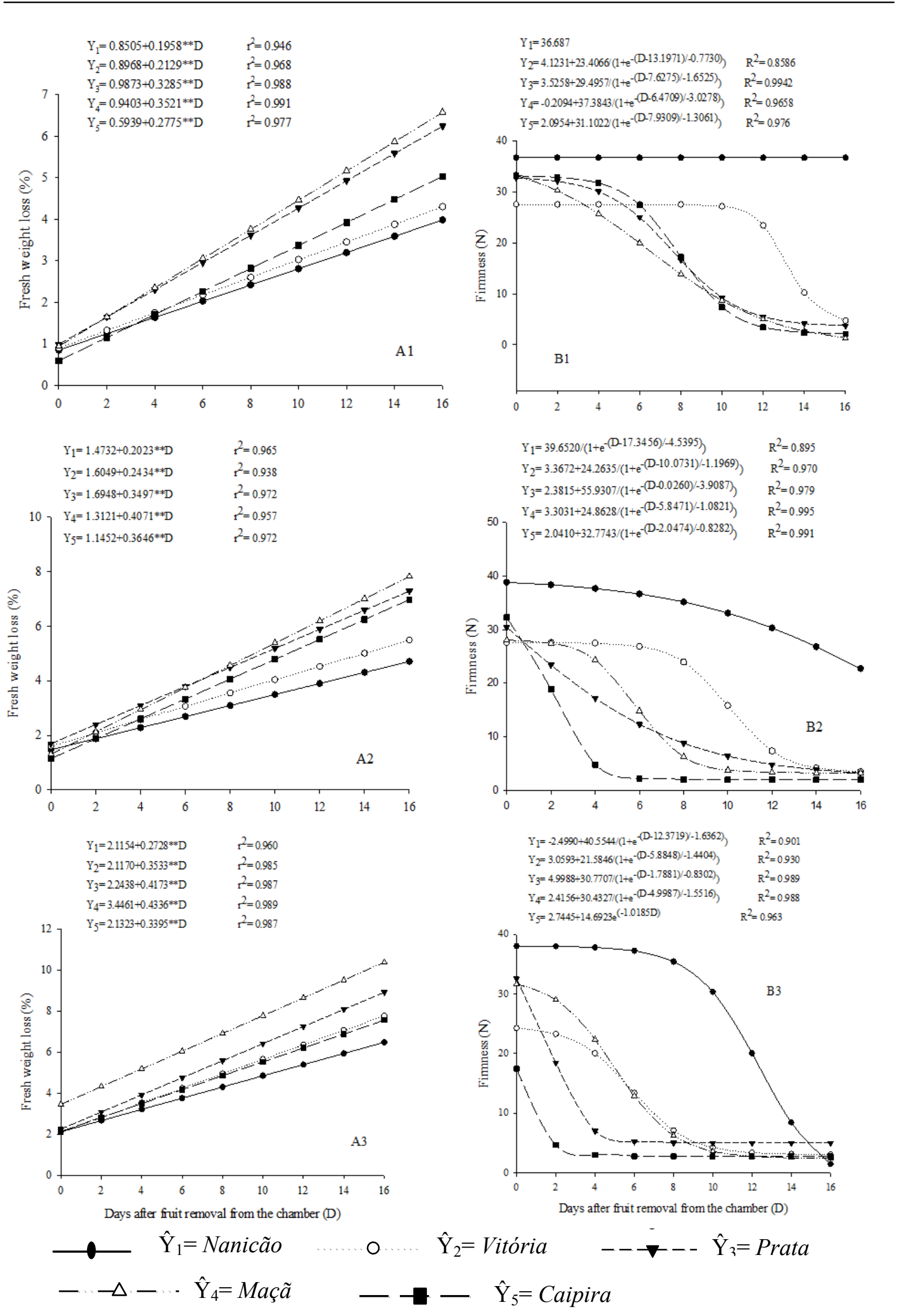

Figure 2. Fresh weight (A) and pulp firmness (B) losses of bananas depending on the periods evaluated after 7 (1), 14 (2) e 21 (3) days of storage at temperature of $10.53 \pm 0.37^{\circ} \mathrm{C}$. ${ }^{* *}$ Significant at $1 \%$ of probability by the ' $t$ ' test. 

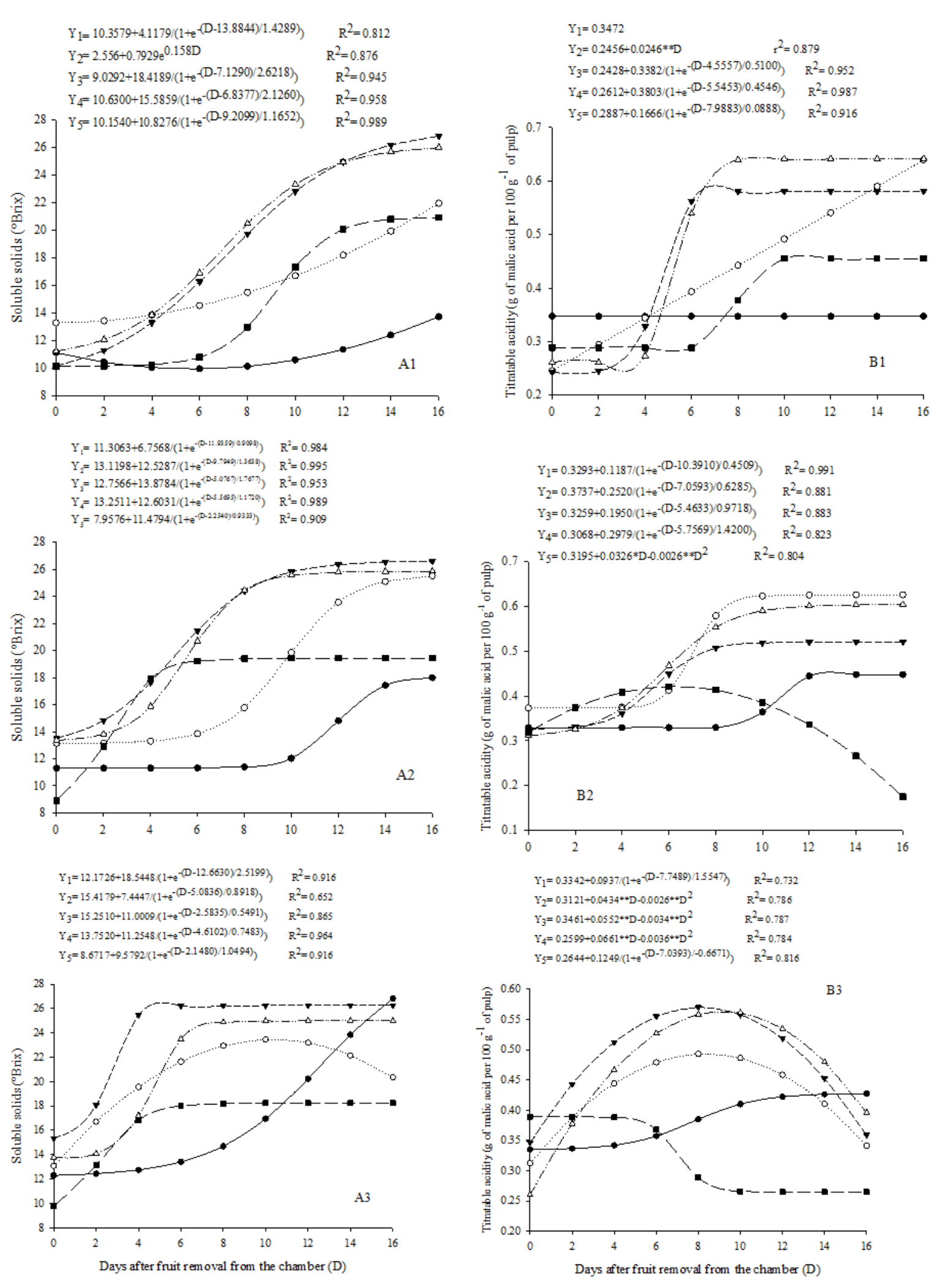

$$
\begin{aligned}
& \longrightarrow \hat{\mathrm{Y}}_{1}=\text { Nanicão } \quad \cdots \cdots \cdots \cdot \hat{\mathrm{Y}}_{2}=\text { Vitória } \quad--\rightarrow--\hat{\mathrm{Y}}_{3}=\text { Prata } \\
& -\Delta-\cdots \hat{\mathrm{Y}}_{4}=\text { Maçã } \quad-\quad \hat{\mathrm{Y}}_{5}=\text { Caipira }
\end{aligned}
$$

Figure 3. Soluble solids content (A) and titratable acidity (B) of bananas depending on the periods evaluated after 7 (1), 14 (2) e 21 (3) days of storage at temperature of $10.53 \pm 0.37^{\circ} \mathrm{C}$. **Significant at $1 \%$ of probability by the ' $t$ ' test.

The soluble solids (SS) of the control fruits were different than the SS of cultivars Prata and
Maçã when stored for 14 and 21 days, and Nanicão when stored for 21 days (Table 1). An average 
increase of $33 \%$ in SS values was found in these fruits compared with the control.

The soluble solids depending on the periods evaluated showed a sigmoidal pattern for the five cultivars in the three storage periods (Figure 3A), except for the Vitória in the SP of 7 days.

In general, the highest SS contents at the end of the three SP were found in the cultivars Prata (26.20 ${ }^{\circ}$ Brix) and Maçã (25.62 ${ }^{\circ}$ Brix) (Figure 3A). The soluble solids content in ripe fruits ranged from 17.7 to $26.8{ }^{\circ}$ Brix. Bezerra and Dias (2009), studying different genotypes of banana, found SS content ranging from 19.84 to $24.82{ }^{\circ}$ Brix in ripe fruits, confirming the values found in the present work. Soluble solids are used as ripening indicators and to establish the quality of the fruit by playing an important role in the fruit flavor (SILVA et al., 2006).

The titratable acidity of the control was no statistically different than those at the end of the storage periods for the cultivars Nanicão and Vitória (Table 1), indicating that these fruits remained in pre -climacteric stage. Lima et al. (2014) found no clear effect of cold storage $\left(14^{\circ} \mathrm{C}\right)$ on the acidity of bananas of cultivar Caipira. However, in the present study, the fruits of the cultivars Prata, Maçã and Caipira presented average titratable acidity value $41.5 \%$ higher than the control after 21 days of storage, indicating the beginning of ripening during the cold storage period.

The titratable acidity depending on the periods evaluated presented a quadratic behavior to cultivars Vitória, Prata and Maçã, after 21 days of cold storage (Figure $3 \mathrm{~B} 3$ ). The titratable acidity values ranged from 0.18 to $0.64 \mathrm{~g}$ of malic acid per $100 \mathrm{~g}$ of pulp in ripe fruits. Values found in the literature (CARVALHO et al., 2011; VIVIANI; LEAL, 2007) are close to those found in this work, ranging from 0.26 to $0.67 \mathrm{~g}$ of malic acid per $100 \mathrm{~g}$ of pulp.

The cultivars Vitória, Prata, Maçã and Caipira ripened to an ideal condition for consumption from the $4^{\text {th }}$ to the $08^{\text {th }}$ day after the 21 days of cold storage, with peel color index of 6 (completely yellow peel), pulp with low resistance (soft) and maximum soluble solids content and titratable acidity.

The chilling injuries in the Nanicão (AAA) stored for 14 and 21 days, and Maçã (AAB) stored for 21 days (Table 2), statistically differed from the control. Light symptoms of browning of the vascular bundles of the peel were observed as soon as the fruits were transferred to the temperature of $22^{\circ}$ $\mathrm{C} \pm 0.39$. The symptoms of chilling injury increased with the cold storage time, although these symptoms have manifested and intensified especially during the evaluation period at $22^{\circ} \mathrm{C} \pm 0.39$ for all cultivars (Figure 4A). Similar results were observed in bananas from the AAA group stored at low temperatures (Wang et al., 2014; WU et al., 2014).

The cultivars Prata and Vitória had the lowest symptoms of chilling injury during the evaluations after 21 days of storage, with average values lower than those found in the Nanicão (32.2\%) Maçã (32.21\%) and Caipira (43.9\%), at the evaluation after 16 days.

Lichtemberg et al. (2001) stored fruits of cultivars Grande Naine (AAA), Prata-Anã (AAB), Mysore (AAB) and FHIA-01 (AAAB) at temperature of $10^{\circ} \mathrm{C}$ and found that the $\mathrm{B}$ genome (Musa balbisiana) provides greater resistance to low temperatures compared to the A genome (Musa acuminata). This characteristic was observed in the present study, since the cultivars Prata (AAB) and Vitória (AAAB) were more tolerant to cold storage, although the Maçã cultivar (AAB) presented symptoms of chilling injury.

Table 2. Scores of chilling injury symptoms and total phenolic compounds and polyphenol oxidase activity of the peel of five banana cultivars before and after different periods of storage at temperature of $10.53 \pm 0.37^{\circ} \mathrm{C}$.

\begin{tabular}{|c|c|c|c|c|c|}
\hline \multirow{2}{*}{ Treatments } & Nanicão & Vitória & Prata & Maçã & Caipira \\
\hline & \multicolumn{5}{|c|}{ Chilling injury } \\
\hline Control $^{1}$ & 1.00 & 1.00 & 1.00 & 1.00 & 1.00 \\
\hline $7 \mathrm{D}$ & 1.00 & 1.00 & 1.00 & 1.00 & 1.00 \\
\hline $14 \mathrm{D}$ & $1.50^{*}$ & 1.00 & 1.00 & 1.00 & 1.00 \\
\hline $21 \mathrm{D}$ & $1.83^{*}$ & 1.00 & 1.00 & $2.00 *$ & 1.00 \\
\hline $\mathrm{CV}^{2}(\%)$ & 22.82 & - & - & 12.45 & - \\
\hline \multicolumn{6}{|c|}{ Total phenolic compounds (Gallic acid equivalent (mg) per $100 \mathrm{~g}$ of fresh matter) } \\
\hline Control $^{1}$ & 42.19 & 39.56 & 53.70 & 29.05 & 42.24 \\
\hline $7 \mathrm{D}$ & $34.48^{*}$ & 36.91 & $37.09 *$ & 22.84 & 37.05 \\
\hline $14 \mathrm{D}$ & $35.97^{*}$ & 37.67 & $41.63 *$ & 28.34 & $29.53 *$ \\
\hline $21 \mathrm{D}$ & $31.45^{*}$ & 34.46 & $38.65^{*}$ & 28.22 & $19.42 *$ \\
\hline $\mathrm{CV}^{2}(\%)$ & 6.10 & 6.73 & 9.70 & 9.97 & 11.07 \\
\hline \multicolumn{6}{|c|}{ Polyphenol oxidase activity of the peel (enzyme unit $\mathrm{g}^{-1}$ ) } \\
\hline Control $^{1}$ & 0 & 0 & 0 & 0 & 0 \\
\hline $7 \mathrm{D}$ & 0 & 0 & 0 & 411.1 & 0 \\
\hline $14 \mathrm{D}$ & $1,144.4$ & 216.7 & 0 & 155.6 & 0 \\
\hline $21 \mathrm{D}$ & 694.4 & 0 & 0 & 794.4 & 155.5 \\
\hline
\end{tabular}

Means followed by * statistically differed from the control by the Dunnett's test, at $5 \%$ of probability;

${ }^{1}$ Mean from the fruits at the storage beginning; ${ }^{2}$ Coeficient of variation. $\mathrm{D}=$ days. 
Chilling injury symptoms are found in bananas at relatively high storage temperatures $\left(12^{\circ}\right.$ C) and increase with decreasing temperature (CHEN et al., 2008).

Bananas are very sensitive to cold compared to other subtropical fruits, such as citrus (HAILU et al., 2013). Fruits are subjected to temperatures slightly below $12^{\circ} \mathrm{C}$, even for a short period, present necrotic points and peel browning. Moreover, secondary symptoms such as lack of aroma, hardening of the pulp and abnormal maturation may also appear (NGUYEN et al. 2003; WANG et al., 2012), hindering the fruit commercialization by affect not only the peel, but the fruit completely.

The total phenolic compounds of the cultivars Nanicão and Prata (after the three storage periods) and Caipira (after 14 days of storage) statistically differed from the control (Table 2). The values of phenolic compounds of these cultivars reduced $35.84 \%$, on average, at the end of the storages. The et al. (2001) found total phenolic contents in pineapple fruits, soon after harvest, statistically higher than the those in cold stored fruits, a result that was also found in the present study.

Total phenolic compounds gradually increased in all cultivars after transferred to a temperature of $22^{\circ} \mathrm{C} \pm 0.39$ (Figure 4B). The cultivars Caipira, Maçã and Nanicão had the lowest values after the storage periods, with levels of 19.80, 27.39 and $31.98 \mathrm{mg}$ (GAE $100 \mathrm{~g}^{-1}$ ), respectively. The highest contents were found in the peel of Prata after the three storage periods, with a maximum value of $60.22,16$ days after the 21 days of storage.

The total phenolic compounds found ranged from 19.80 to $60.22 \mathrm{mg} 100 \mathrm{~g}^{-1}$ of GAE. Sulaiman et al. (2011) evaluated the antioxidant capacity of eight banana cultivars in Malaysia and found maximum total phenolic compounds of $76.37 \mathrm{mg} 100 \mathrm{~g}^{-1}$ of GAE in the peel.

Phenolic compounds are considered as one of the causal factors of browning of fruits, they have also a protective function against Reactive Oxygen Species (ROS), which include superoxide anions $(\mathrm{O} \bullet$ -), hydroxyl radicals $(\mathrm{OH} \bullet)$ and hydrogen peroxide $\left(\mathrm{H}_{2} \mathrm{O}_{2}\right)$ that cause lipid peroxidation, damaging the organelles (DE MARTINO et al., 2006). Vieira et al. (2009) found that apple cultivars resistant to scab have higher content of phenolic compounds in the peel compared to susceptible cultivars. Similarly, the cultivar Prata showed high tolerance to chilling and the highest total phenolic content in the present work.

The activity of polyphenol oxidase (PPO) of the peel increased during the storage period (Table 2) and during the evaluations after the cold storage for most cultivars (Figure 5). The PPO enzyme is found in virtually all plant tissues, and its activity depends on the species, growing conditions and maturation stage (CORREA et al., 2007). An increase in this enzyme activity was observed during the ripening of apples (COSETENG; LEE, 1987), as in the present study for bananas; this result was the opposite for jabuticabas (VIEITES et al., 2011) and avocados (VIEITES et al., 2012).

The bananas Maçã cold stored for 7 days had the highest PPO activity values during the 16 days of evaluations at $22 \pm 0.39^{\circ} \mathrm{C}$, with a peak of $6,106 \mathrm{UE} \mathrm{g}$ 1 . Bananas Prata had the lowest PPO activity values after 14 days of cold storage, with average of 87.9 UE $\mathrm{g}^{-1}$. The increase in polyphenol oxidase enzyme activity was 41.2-fold in bananas Maçã, (Figure 5A). Bananas Prata and Vitória had the lowest PPO values after 21 days of cold storage, with peaks of 283 and $609 \mathrm{UE} \mathrm{g}^{-1}$, respectively, while the highest activities of PPO were observed in cultivars Maçã, Caipira and Nanicão, with peaks of 7,556, 2,806 and 2,128 $\mathrm{EU} \mathrm{g}^{-1}$, respectively (Figure 5C). Higher values of PPO in the peel are consistent with the symptoms of chilling injury in the fruits of these three cultivars (Figure 4A).

The PPO is a terminal oxidase of great occurrence in plants, which catalyzes the oxidation of phenolic compounds, resulting in browning of tissues through the conversion of monophenols into diphenols (monofenol oxidase activity) and oxidation of diphenols (the difenol oxidase activity) (ZHANG; QUANTICK, 1997). This oxidation occurs as a result of disruption of membranes after the tissue exposure to low temperatures, releasing phenolic compounds that were stored in vacuoles, which are deposited on the cell walls, contacting the oxidative enzymes peroxidase and polyphenol oxidase (NGUYEN et al., 2003).

The increased in polyphenol oxidase activity found confirms the stress caused to the fruits by storage at low temperature. The peel browning due to the activity of oxidative enzymes results in an unpleasant appearance to consumers, and may alter the banana taste. Fruits with these symptoms are rejected and often discarded in more exigent markets, contributing to food waste. 


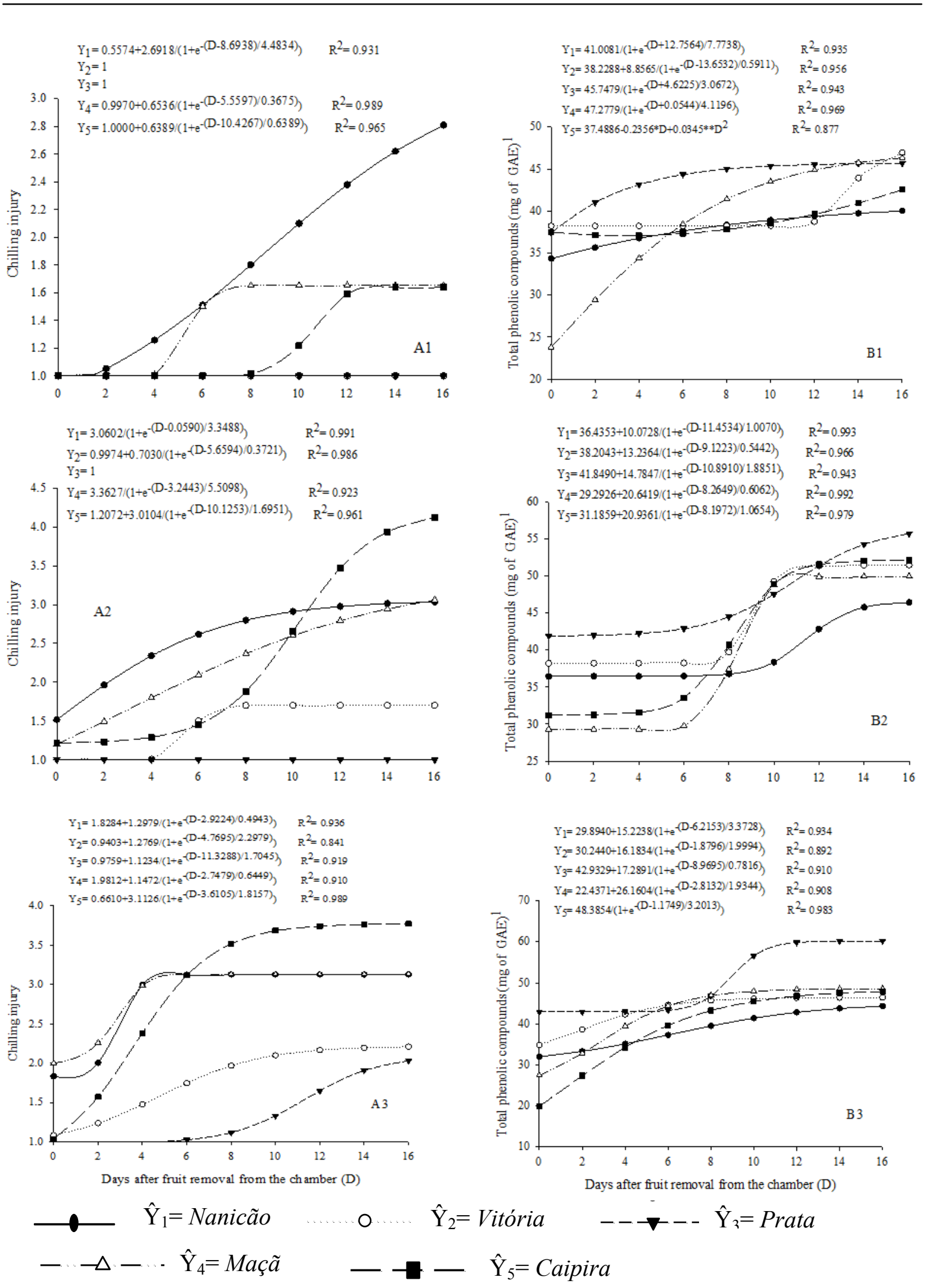

Figure 4. Chilling injury scores (A) and total phenolic compounds of the peel (B) of bananas as a function of the periods evaluated, after 7 (1), 14 (2) e 21 (3) days of storage at temperature of $10.53 \pm 0.37^{\circ} \mathrm{C} ;{ }^{1}$ Gallic acid equivalent (mg) per $100 \mathrm{~g}$ of fresh matter; * and $* *=$ significant at $5 \%$ and $1 \%$ of probability, respectively, by the ' $\mathrm{t}$ ' test. 

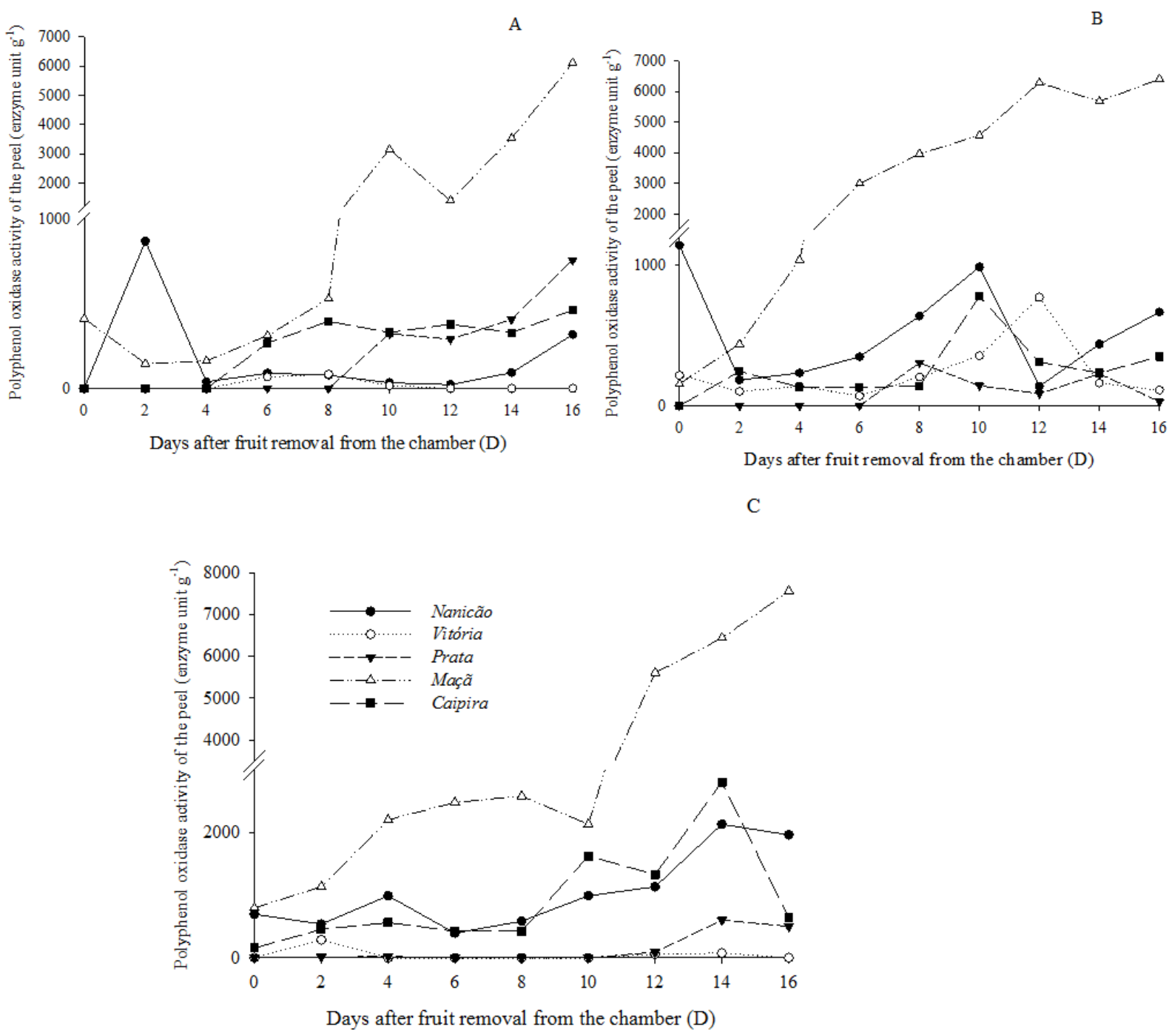

Figure 5. Activity of polyphenol oxidase of banana peel of different cultivars as a function of the periods evaluated, after 7 (1), 14 (2) e 21 (3) days of storage at temperature of $10.53 \pm 0.37^{\circ} \mathrm{C}$.

\section{CONCLUSIONS}

Bananas of the cultivars Prata (AAB) and Vitória (AAAB) were more tolerant to cold storage at temperature of $10.53 \pm 0.37^{\circ} \mathrm{C}$ for up to 21 days and presented normal ripening after transferred to a temperature of $22 \pm 0.39^{\circ} \mathrm{C}$.

The increase in storage time $\left(10.53 \pm 0.37^{\circ} \mathrm{C}\right)$ increased the intensity of damage to fruits of cultivars Caipira, Maçã and Nanicão.

\section{ACKNOWLEDGEMENTS}

The authors thank the Coordination for the Improvement of Higher Education Personnel (CAPES) and the National Counsel of Technological and Scientific Development (CNPq) for granting study and research productivity scholarships.

\section{REFERENCES}

BEZERRA, V. S.; DIAS, J. S. A. Avaliação físicoquímica de frutos de bananeiras. Acta Amazonica, Manaus, v. 39, n. 2, p. 423-427, 2009.

CARVALHO, A. V. et al. Qualidade pós-colheita de cultivares de bananeira do grupo 'Maçã', na região de Belém, PA. Revista Brasileira de Fruticultura, Jaboticabal, v. 33, n. 4, p. 1095-1102, 2011.

CHEN, J. Y. et al. Role of phenylalanine ammonialyase in heat pretreatment-induced chilling tolerance in banana fruit. Physiologia Plantarum, Malden, v. 132, n. 3, p. 318-328, 2008.

CHITARRA, M. I. F. et al. Pós-colheita de frutas e hortaliças: físiologia e manejo. 2. ed. Lavras, MG: Universidade Federal de Lavras, 2005. 785 p.

CORRÊA, M. O. G.; PINTO, D. D.; ONO, E. O. Análise da atividade respiratória em frutos de jabuticabeira. Revista Brasileira de Biociências, Porto Alegre, v. 5, n. 2, p. 831-833, 2007. 
COSETENG, M. Y.; LEE, C. Y. Changes in apple polyphenoloxidase and polyphenol concentrations in relation to degree of browning. Journal of Food Science, New York, v. 52, n. 4, p. 985-989, 1987.

DADZIE，B. K.; ORCHARD, J. E. Evaluación rutinaria postcosecha de híbridos de bananos $\mathrm{y}$ plátanos: criterios y métodos. Montpelier: INIBAP, 1997. 63 p. (Inibap. Guias técnicas, 2).

DE MARTINO, G. et al. 1-MCP controls ripening induced by impact injury on apricots by affecting SOD and POX activities. Postharvest Biology and Technology, Amsterdam, v. 39, n. 1, p. 38-47, 2006.

FOOD AND AGRICULTURE ORGANIZATION OF THE UNITED NATIONS. FaoStat. Disponível em: $\quad<$ http://faostat.fao.org/site/339; defaut.aspx $>$. Acessado em: 14 jun. 2014.

FERNANDES, E.G.; LEAL, P.A.M.; SANCHES, J. Climatização e armazenamento refrigerado na qualidade pós-colheita de bananas 'Nanicão'. Bragantia, Campinas, v.69, p.735-743, 2010.

FINGER, F. L.; PUSCHMANN, R.; BARROS, R. S. Effects of water loss on respiration, ethylene production and ripening of banana fruit. Revista Brasileira de Fisiologia Vegetal, Campinas, v. 7, n. 1, p. 115-118, 1995.

FLURKEY, W. H.; JEN, J. J. Peroxidase e polyphenol oxidase activities in developing peaches. Journal of Food Science, Malden, v. 43, n. 6, p. 1826-1831, 1978

HAILU, M. WORKNEH, T. S.; BELEW, D. Review on postharvest technology of banana fruit. African Journal of Biotechnology, Grahamstown, v. 12, n. 7, p. 635-647, 2013.

INSTITUTO ADOLFO LUTZ. Normas Analíticas do Instituto Adolfo Lutz. Métodos físico-químicos para análise de alimentos, 4. ed., 1ํㅡㄹ. Digital, São Paulo: IAL, 2008, 1020 p

LICHTEMBERG, L. A.; LICHTEMBERG, P. S. F. Avanços na bananicultura brasileira. Revista Brasileira de Fruticultura, Jaboticabal, Sup., p. 2936, 2011.

LICHTEMBERG, L. A.; MALBURG, J. L.; HINZ, R. H. Cold damage in bananas. Revista Brasileira de Fruticultura, Jaboticabal, v. 23, n. 3, p .568-572, 2001.

LIMA, O. S. et al. Ripening and shelf life of 'BRS Caipira' banana fruit stored under room temperature or refrigeration. Ciência Rural, Santa Maria, v. 44, n. 4, p. 734-739, 2014
MAIA, V. M. et al. Physical and metabolic changes induced by mechanical damage in 'dwarf-prata' banana fruits kept under cold storage. Australian Journal of Crop Science, Inala, v. 8, n. 7, p. 10291037, 2014.

MARTINS, R.N. et al. Armazenamento refrigerado de banana 'Prata-Anã' proveniente de cachos com 16, 18 e 20 semanas. Ciência e Agrotecnologia Lavras, v. 31, n. 5, p. 1423-1429, 2007.

MATSUURA, F. C. A. U.; COSTA, J. I. P.; FOLEGATTI, M. I. S. Marketing de banana: preferências do consumidor quanto aos atributos de qualidade dos frutos. Revista Brasileira de Fruticultura, Jaboticabal, v. 26, n. 1, p. 48-52, 2004

NGUYEN, T. B.; KETSA, S.; VAN DOORN, W. G. Relationship between browning and the activities of polyphenol oxidase and phenylalanine ammonia lyase in banana peel during low temperature storage. Postharvest Biology and Technology, Amsterdam, v. 30, n. 2, p. 187-193, 2003.

PROMYOU, S.; KETSA, S.; VAN DOORN, W. G Hot water treatments delay cold-induced banana peel blackening. Postharvest Biology and Technology, Amsterdam, v. 48, n. 1, p. 132-138, 2008.

SAEG. SISTEMA PARA ANÁlISES ESTATÍSTICAS, versão 9.1: Fundação Arthur Bernardes, UFV, Viçosa, MG, 2007.

SILVA, E. A.; BOLIANI, A. C.; CORRÊA, L. S. Avaliação de cultivares de bananeira (Musa sp) na região de Selvíria - MT. Revista Brasileira de Fruticultura, Jaboticabal, v. 28, n. 1, p. 101-103, 2006.

SINGLETON, V. L.; ORTHOFER, R.; LAMAUELA-RAVENTÓS, R. M. Analysis of total phenols and other oxidation substrates and antioxidantes by means of Folin-Ciocalteu reagent. Methods in Enzymology, Amsterdam, v. 299, n. 1, p. 152-178, 1999.

SULAIMAN, S. F. et al. Correlation between total phenolic and mineral contents with antioxidant activity of eight Malaysian bananas (Musa sp.). Journal of Food Composition and Analysis, Amsterdam, v. 24, n. 1, p. 1-10, 2011.

THÉ, P. M. P. et al. Efeito da temperatura de armazenamento e do estádio de maturação sobre a composição química do abacaxi cv. Smooth Cayenne L. Ciência e Agrotecnologia, Lavras, v. 25, n. 2, p. 356-363, 2001

VIEIRA, F. G. K. et al. Physico-chemical and 
antioxidant properties of six apple cultivars (Malus domestica Borkh). Scientia Horticulturae, Amsterdam, v. 122, n. 3, p. 421-425, 2009.

VIEITES, R. L. et al. Caracterização físico-química, bioquímica e funcional da jabuticaba armazenada sob diferentes temperaturas. Revista Brasileira de Fruticultura, Jaboticabal, v. 33, n. 2, p. 362-375, 2011.

VIEITES, R. L.; DAIUTO, E. R.; FUMES, J. G. F. Capacidade antioxidante e qualidade pós-colheita de abacate 'Fuerte'. Revista Brasileira de Fruticultura, Jaboticabal, v. 34, n. 2, p. 336-348, 2012.

VIVIANI, L.; LEAL, P. M. Qualidade pós-colheita de banana Prata-Anã armazenada sob diferentes condições. Revista Brasileira de Fruticultura, Jaboticabal, v. 29, n. 3, p. 465-470, 2007.

WANG, H. et al. The effect of delay between heat treatment and cold storage on alleviation of chilling injury in banana fruit. Journal of the Science of Food and Agriculture, v. 92, n. 13, p. 2624-2629, 2012.

WANG, Y. et al. Effect of exogenous $\gamma$ aminobutyric acid (GABA) treatment on chilling injury and antioxidant capacity in banana peel. Scientia Horticulturae, Amsterdam, v. 168, n. 1, p. 132-137, 2014.

WU, B. et al. Impact of postharvest nitric oxide treatment on antioxidant enzymes and related genes in banana fruit in response to chilling tolerance. Postharvest Biology and Technology, Amsterdam, v. 92, n. 1, p. 157-163, 2014.

XIAO, Y.; CHEN, J.; LU, W. Banana ethylene response factors are involved in fruit ripening through their interactions with ethylene biosynthesis genes. Journal of Experimental Botany, Oxford, v. 64, n. 8, p. 2499-2510, 2013.

ZHANG, D.; QUANTICK, P. C. Effects of chitosan coating on enzymatic browning and decay during postharvest storage of litchi (Litchi chinensis Sonn) fruit. Postharvest Biology and Technology, Amsterdam, v. 12, n. 2, p. 195-202, 1997.

ZHANG, H. et al. Physiology and quality response of harvested banana fruit to cold shock. Postharvest Biology and Technology, Amsterdam, v. 55, n. 3, p. 154-159, 2010. 